\title{
Bioproduction of succinic acid from xylose by engineered Yarrowia lipolytica without $\mathrm{pH}$ control
}

\author{
Ashish A. Prabhu', Rodrigo Ledesma-Amaro², Carol Sze Ki Lin, Frederic Coulon', Vijay Kumar Thakur ${ }^{4}$ \\ and Vinod Kumar ${ }^{1 *}$ (B)
}

\begin{abstract}
Background: Xylose is the most prevalent sugar available in hemicellulose fraction of lignocellulosic biomass (LCB) and of great interest for the green economy. Unfortunately, most of the cell factories cannot inherently metabolize xylose as sole carbon source. Yarrowia lipolytica is a non-conventional yeast that produces industrially important metabolites. The yeast is able to metabolize a large variety of substrates including both hydrophilic and hydrophobic carbon sources. However, Y. lipolytica lacks effective metabolic pathway for xylose uptake and only scarce information is available on utilization of xylose. For the economica feasibility of LCB-based biorefineries, effective utilization of both pentose and hexose sugars is obligatory.
\end{abstract}

Results: In the present study, succinic acid (SA) production from xylose by Y. lipolytica was examined. To this end, $Y$. lipolytica PSA02004 strain was engineered by overexpressing pentose pathway cassette comprising xylose reductase $(X R)$, xylitol dehydrogenase $(X D H)$ and xylulose kinase $(X K)$ gene. The recombinant strain exhibited a robust growth on xylose as sole carbon source and produced substantial amount of SA. The inhibition of cell growth and SA formation was observed above $60 \mathrm{~g} / \mathrm{L}$ xylose concentration. The batch cultivation of the recombinant strain in a bioreactor resulted in a maximum biomass concentration of $7.3 \mathrm{~g} / \mathrm{L}$ and $S A$ titer of $11.2 \mathrm{~g} / \mathrm{L}$ with the yield of $0.19 \mathrm{~g} / \mathrm{g}$. Similar results in terms of cell growth and SA production were obtained with xylose-rich hydrolysate derived from sugarcane bagasse. The fed-batch fermentation yielded biomass concentration of $11.8 \mathrm{~g} / \mathrm{L}\left(\mathrm{OD}_{600}: 56.1\right)$ and SA titer of $22.3 \mathrm{~g} / \mathrm{L}$ with a gradual decrease in $\mathrm{pH}$ below 4.0. Acetic acid was obtained as a main by-product in all the fermentations.

Conclusion: The recombinant strain displayed potential for bioconversion of xylose to SA. Further, this study provided a new insight on conversion of lignocellulosic biomass into value-added products. To the best of our knowledge, this is the first study on SA production by Y. lipolytica using xylose as a sole carbon source.

Keywords: Xylose, Yarrowia lipolytica, Succinic acid, Acetic acid, pH

\section{Background}

Microbial conversion of renewable biomass such as lignocellulosic feedstock into value-added products is getting a humongous response as it can replace the dependency on

*Correspondence: Vinod.Kumar@cranfield.ac.uk

1 School of Water, Energy and Environment, Cranfield University, Cranfield MK43 OAL, UK

Full list of author information is available at the end of the article petroleum-based refineries, majorly responsible for rapid climate change and greenhouse gas emission [1]. Lignocellulosic biomass (LCB) is an abundant and rich source of renewable carbon and considered as a prominent feedstock to produce chemical commodities. LCB is a threedimensional polymeric material composed of cellulose, hemicellulose and lignin. Cellulose is a linear homo-polymer of D-glucose while hemicellulose is a hetero-polymer. Xylose is the predominant sugar in hemicellulose 
and can constitute up to $30-40 \%$ of LCB [2]. Most of the studies are however focused on the utilization of cellulose for manufacturing value-added products, while the hemicellulosic portion is usually discarded as most microbes lack an efficient pathway for utilization of pentose sugar. In addition, carbon catabolite repression suppresses the assimilation of pentose sugars including xylose [3]. Therefore, efficient bioconversion of xylose is a prerequisite for economic feasibility of lignocellulosic biorefineries. Hence, more attention is paid to the rewiring of metabolic networks of microbial strains to utilize multiple carbon sources simultaneously, especially glucose and xylose, from the feedstock which will be essential for derisking the commercial viability of the bioprocesses $[2,4]$.

Succinic acid (SA) $\left(\mathrm{C}_{4} \mathrm{H}_{6} \mathrm{O}_{4}\right)$, is one of the 12 highvalue bio-based chemicals listed by the US Department of Energy, and it has wide range of industrial applications [5]. Due to its versatility, the global market of SA is expanding with a demand of 50,000 metric ton in 2016 which is expected to double by 2025 [6, 7]. The chemical routes for SA synthesis are not only unsustainable, but they also suffer from reduced yield and low purity of the main product. As a result, in recent years, there is a growing interest towards creating a cleaner and greener technology for SA production and paradigm shift from petrochemical synthesis towards bio-based production of SA [8]. Currently, the bio-based production of SA constitute a significant fraction of the total market [9]. Despite the high potential, the growth of bio-based SA production witnessed a declining trend in recent years. Due to low petroleum prices, fossil-based SA production is cheaper than SA synthesized through biological route. Therefore, it is imperative to cut down the cost to make it economically viable and the utilization of crude renewable resources from waste streams could substantially reduce the production cost of SA. It is envisaged that with the use of low-cost agricultural feedstock, bioproduction will soon replace the conventional petroleumbased process $[9,10]$.

The fermentative production of SA occurs through the reductive and/or oxidative TCA cycle, utilization of $\mathrm{CO}_{2}$ as co-substrate which leads to high $\mathrm{CO}_{2}$ sequestration potential [11]. The biological production of SA has been investigated using several bacterial strains such as Mannheimia succiniciproducens, Actinobacillus succinogenes and recombinant Escherichia coli as a potential host [12]. Bacteria are very sensitive towards low $\mathrm{pH}$ and require moderate $\mathrm{pH}$ for their growth resulting in large consumption of neutralizing agent [11]. Further at neutral $\mathrm{pH}, \mathrm{SA}$ is obtained in the form of succinate salts which complicates the downstream processing, and all these add extra cost to bioprocess. On the other hand, yeasts are the potential host to produce organic acids as they are naturally adapted to grow under low pH [13]. Yarrowia lipolytica is an oleaginous, non-conventional, robust and industrially important yeast with GRAS status. Being an aerobic yeast, the flux of TCA cycle is very active in $Y$. lipolytica and plethora of reports are based on the production of TCA intermediates including SA by the yeast $[14,15]$. Furthermore, $Y$. lipolytica has the amazing ability to grow perfectly well over a wide $\mathrm{pH}$ range without any significant change in growth parameters [16]. All these features render this yeast species as an attractive host to produce SA.

Over the years, extensive efforts have been made to make it a superior host. Previously, Y. lipolytica has been engineered for production SA using glucose and glycerol as carbon sources $[17,18]$. Most studies claimed that $Y$. lipolytica cannot naturally use xylose as the sole carbon source [19] and there is no report on xylose-based SA production by $Y$. lipolytica. In the present study, attempts were made to overexpress pentose pathway genes in Y. lipolytica. To this end, Y. lipolytica PSA02004 strain was engineered by overexpression of xylose reductase $(X R)$, xylitol dehydrogenase $(X D H)$ and xylulose kinase $(X K)$ genes for efficient utilization of xylose and simultaneous production of SA (Fig. 1). The recombinant strain was grown on xylose, and the impact of co-substrates on cell growth and xylose metabolism were examined. To further visualize the maximum carbon uptake capability and product formation, the strain was subjected to different concentrations of xylose. The study was scaled up from shake flask to bioreactor with batch and fed-batch cultivations to further improve SA production. The engineered strain was also evaluated for SA production from xylose-rich hydrolysate derived from sugarcane bagasse (SCB). The $\mathrm{pH}$ was not controlled in any of the experiments carried out in this work in order to understand the robustness of the strain to withstand low $\mathrm{pH}$ conditions, without compromising the production. To our knowledge, this is the first report of SA production in Y. lipol$y$ tica with xylose as the sole carbon source.

\section{Results}

\section{Shake flask cultivation of $Y$. lipolytica PSA02004}

$\mathrm{SA}$ is an intermediate of TCA cycle and produced through oxidative/reductive TCA cycle [20]. The reductive pathway is not favorable thermodynamically and responsible for glucose repression. Y. lipolytica prefers to use oxidative TCA cycle for SA production [21, 22]. Succinate dehydrogenase is one of the enzymes of oxidative TCA cycle, which catalyzes the oxidation of succinate to fumarate and it has five subunits. Gao et al. inactivated $s d h 5$ encoding succinate dehydrogenase assembly factor 2 (YALIOF11957g) in Po1f strain (derived from W29 strain) and obtained a mutant PGC01003 [23], 
and this strain showed impaired growth on glucose. The PGC01003 strain was subjected to adaptive evolution using glucose-based medium for 21 days and the evolved strain was designated as Y. lipolytica PSA02004 [18]. This strain was cultured on glucose, glycerol, xylose, glucose/ xylose and glycerol/xylose (Fig. 2). Glucose and glycerol are the preferred carbon sources for Y. lipolytica, and these carbon sources were completely depleted within $72 \mathrm{~h}$ concomitant with the cell growth, which also coincided with SA production (5.0-6.0 g/L) (Fig. 2a, c). However, the strain was unable to grow on xylose as the sole carbon source (data not shown). The co-fermentation of xylose with glucose or glycerol resulted in xylitol accumulation along with SA synthesis (6.5-8.0 g/L) (Fig. 2b, d) indicating that $Y$. lipolytica cannot metabolize xylose to grow on it, but it can transform xylose into xylitol with a high conversion yield ( 70\%). This was also supported by similar cell growth $\left(\mathrm{OD}_{600}: 20-22\right)$ observed on glucose/ glycerol, as well as during co-fermentation with xylose, where xylose was mainly utilized for xylitol synthesis and not contributing for biomass/product manufacturing. The xylose was subjected to carbon catabolite repression in the presence of glucose/glycerol, and rapid consumption of xylose along with xylitol accumulation started after $48 \mathrm{~h}$ when large fraction of these co-substrates was utilized. Acetic acid (AA) was obtained as a main byproduct, which was evident in the late log phase of the cell growth, it can be correlated with subsequent drop in $\mathrm{pH}$ below 4.5 in all the fermentations. Another important observation was that the amount of SA and AA achieved during co-fermentation was marginally higher in comparison to fermentation on a single carbon source hinting at cryptic xylose metabolism in Y. lipolytica.

\section{Introduction of xylose metabolic pathway in Y. lipolytica PSA02004}

As shown in previous section, Y. lipolytica PSA02004 strain showed no growth on minimal medium supplemented with $20 \mathrm{~g} / \mathrm{L}$ xylose as a sole carbon source. The inability of $Y$. lipolytica to assimilate xylose for cellular growth impedes its application for lignocellulosic biorefineries. To enable growth on xylose, xylose metabolic pathway was introduced in Y. lipolytica PSA02004. In this study, the engineered strain was constructed by overexpressing the homologous gene of xylose reductase $(X R)$, xylitol dehydrogenase $(X D H)$ and of xylulose kinase $(X K)$ from Y. lipolytica (Pold strain) cloned under transcription elongation factor (TEF) promoter (Fig. 3a). The resulting strain was designated as $Y$. lipolytica PSA02004PP. With the overexpression of $X R, X D H$ and $X K$, the strain was able to grow in the medium containing xylose as a sole carbon source. The time course profiles of substrate assimilation, cell growth, product formation and $\mathrm{pH}$ were similar to those obtained on glucose or glycerol. There was no xylitol accumulation and probably, all the formed xylitol was funneled towards central carbon metabolism. The maximum $\mathrm{OD}_{600}$ obtained was 14.1 at $72 \mathrm{~h}$. The recombinant strain PSA02004PP was able to produce $3.8 \mathrm{~g} / \mathrm{L}$ SA from xylose with $0.19 \mathrm{~g} / \mathrm{g}$ yield. Interestingly, substantial amount of AA ( $4.1 \mathrm{~g} / \mathrm{L})$ was accumulated. The combined production of two organic acids resulted in drop in $\mathrm{pH}$ with time (Fig. 3b). In addition to cultivation on xylose, the activity of two key enzymes, i.e., $\mathrm{XR}$ and $\mathrm{XDH}$, involved in xylose metabolism was monitored throughout fermentation (Fig. 3c). The activity profiles revealed that high activities of XR and XDH were maintained during exponential growth and stationary phase. The maximum XR and XDH activity of 0.85 and $0.98 \mathrm{U} / \mathrm{mg}$, respectively, were obtained at $72 \mathrm{~h}$. The slightly high XDH activity than XR allows better synchronization between two enzymes, and results in efficient conversion xylose to xylulose without accumulation of xylitol as by-product.

\section{Co-fermentation of xylose with glucose/glycerol by $Y$. lipolytica PSA02004PP in shake flasks}

The recombinant $Y$. lipolytica strain carrying a copy of $X R, X D H$ and $X K$ gene showed a superior growth characteristic along with SA synthesis in xylose containing medium under shake flask cultivation. Furthermore, the phenotypic profile on different carbon sources such as glycerol and glucose, and the effect of these substrates on the uptake of xylose were investigated. The recombinant strain produced SA titer of 5.7 and $5.0 \mathrm{~g} / \mathrm{L}$ with glycerol and glucose as carbon source, respectively (Fig. 4a, c). While in case of co-fermentation with glucose or glycerol, the consumption of xylose was slowed down, indicating some signs of catabolite repression effect. The co-fermentation of glucose and xylose resulted in the maximum $\mathrm{OD}_{600}$ value of 22.7 with SA titer of $9.9 \mathrm{~g} / \mathrm{L}$ at $96 \mathrm{~h}$ (Fig. 4b). While $\mathrm{OD}_{600}$ of 30.1 was achieved with similar resultant SA concentration $(10.0 \mathrm{~g} / \mathrm{L})$ at a faster rate in $72 \mathrm{~h}$ using a mixture of glycerol and xylose (Fig. 4d). Additional accumulation of AA was observed both in individual sugars as well as with mixed substrates, which also reduced the $\mathrm{pH}$ of the fermentation broth besides reducing the SA yield. After the introduction of xylose metabolic pathway, no xylitol accumulation was observed with co-fermentations, and significant improvement in SA synthesis was noticed in comparison to control where xylose was transformed into xylitol in presence of glucose/glycerol. Thus, there was clear shift in metabolism with entry of xylose into central carbon metabolism. 


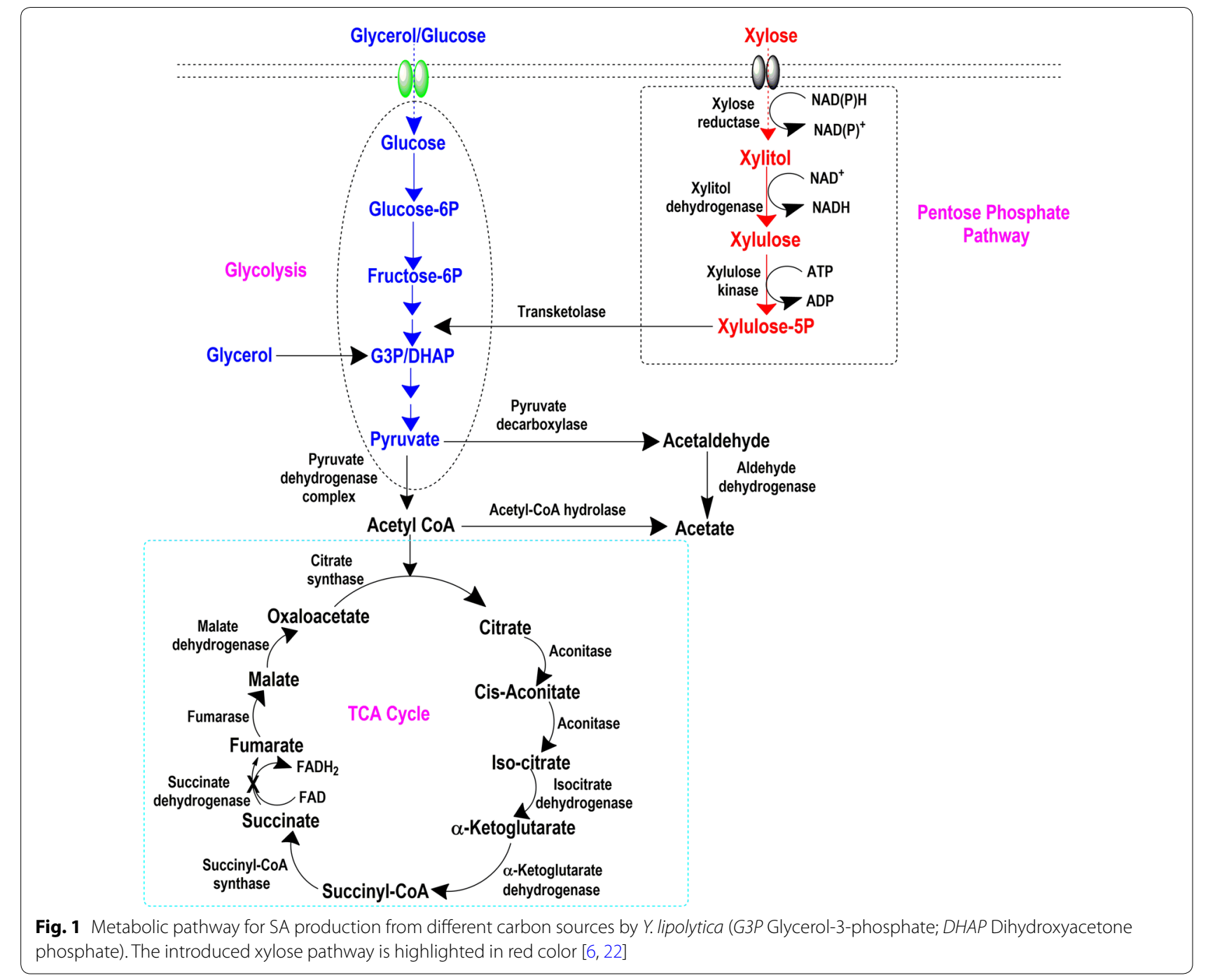

\section{Substrate inhibition studies on recombinant $Y$. lipolytica PSA02004PP}

The effects of initial xylose concentration on the substrate uptake rate, cell growth, product and by-product formation ability of Y. lipolytica PSA02004PP were investigated by growing the strain at different initial concentrations of xylose ranging from 20 to $120 \mathrm{~g} / \mathrm{L}$. The aim of the experiment was to determine optimal level of xylose for cell growth and SA production. Figure 5a-e shows the time course profiles for xylose uptake, cell growth $\left(\mathrm{OD}_{600}\right)$, SA, AA and xylitol production. Xylose was completely consumed in $72 \mathrm{~h}$ for fermentation media with an initial level of 20 and $40 \mathrm{~g} / \mathrm{L}$. Beyond $40 \mathrm{~g} / \mathrm{L}$, residual xylose was noticed even at $120 \mathrm{~h}$. The uptake of xylose was reduced after $48 \mathrm{~h}$ at $60,80,100$ and $120 \mathrm{~g} / \mathrm{L}$. The amount of unutilized xylose at 60, 80, 100 and $120 \mathrm{~g} / \mathrm{L}$ was 8.6, 36.1, 51.9 and $77.3 \mathrm{~g} / \mathrm{L}$, respectively (Fig. $5 \mathrm{a}$ ). There was a linear increase in cell growth (i.e., $\mathrm{OD}_{600}$ ) from 11.7 to 17.2 , as the initial xylose concentration was enhanced from $20 \mathrm{~g} / \mathrm{L}$ to $60 \mathrm{~g} / \mathrm{L}$ (Fig. 5b). Above $60 \mathrm{~g} / \mathrm{L}$, there was gradual decline in the biomass formation indicating the substrate inhibition. Similar trend was obtained with SA; producing a maximum of 3.8, 6.6 and $10.0 \mathrm{~g} / \mathrm{L}$ at 20,40 and $60 \mathrm{~g} / \mathrm{L}$ initial xylose concentration, respectively (Fig. 5c). Further increase in initial xylose concentration retarded the yield and productivity of SA. AA was identified as the main by-product and accumulation enhanced at higher substrate concentration. The AA level reached 10-13 g/L at initial xylose concentration 80-120 g/L (Fig. 5d). Interestingly, xylitol formation was observed at xylose level above $40 \mathrm{~g} / \mathrm{L}$ and significantly increased from $1.3 \mathrm{~g} / \mathrm{L}$ to $10.5 \mathrm{~g} / \mathrm{L}$ as initial xylose concentration was raised from $60 \mathrm{~g} / \mathrm{L}$ to $120 \mathrm{~g} / \mathrm{L}$ (Fig. 5e). The continuous increment in AA and xylitol production with increase in xylose levels can be due to overflow metabolism at higher substrate concentrations. The initial xylose concentration of $60 \mathrm{~g} / \mathrm{L}$ 


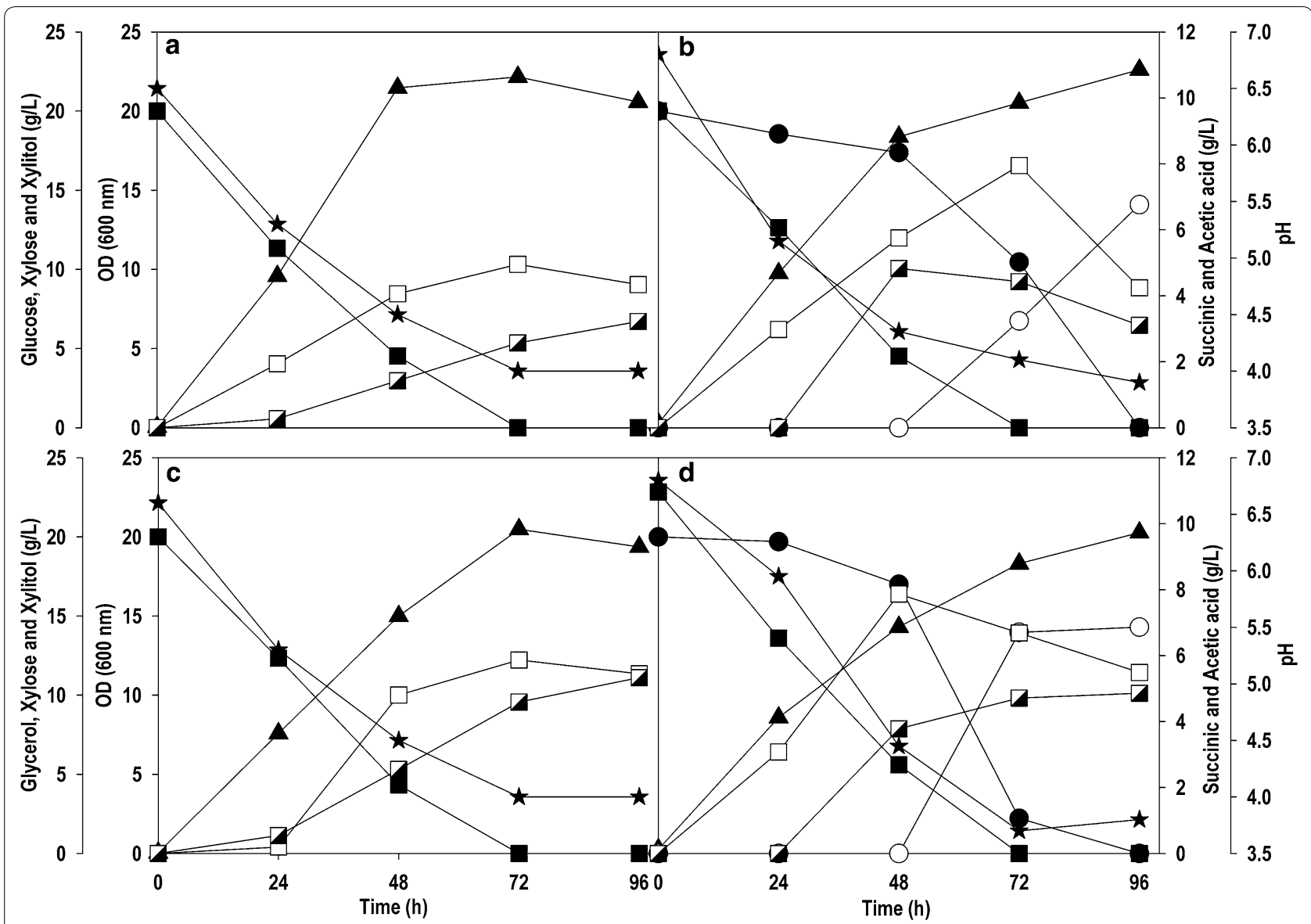

Fig. 2 Time-course profiles of substrate consumption, $\mathrm{OD}_{600}, \mathrm{pH}$, production of $\mathrm{SA}$, $\mathrm{AA}$ and $x y$ litol during shake flask culture of $Y$. lipolytica PSA02004 on a glucose, $\mathbf{b}$ glucose + xylose, $\mathbf{c}$ glycerol and $\mathbf{d}$ glycerol + xylose. Symbols: filled square (glucose or glycerol), filled triangle up (OD $\left.{ }_{600}\right)$, empty square (SA), semi-filled right square (AA), filled circle (xylose), empty circle (xylitol) and filled star ( $\mathrm{pH}$ )

was selected for further experiments to achieve an optimal balance between SA titer, yield and productivity.

\section{Batch cultivation of Y. lipolytica PSA02004PP in bench-top-scale bioreactor}

The batch cultivation of recombinant $Y$. lipolytica PSA02004PP was conducted in bench-top bioreactor in order to understand the phenotypic characteristic of strain. The initial concentration of pure xylose was $60 \mathrm{~g} / \mathrm{L}$. The strain was able to produce maximum biomass concentration of $7.3 \mathrm{~g} / \mathrm{L}\left(\mathrm{OD}_{600}: 34.9\right)$ with pure xylose substrate (Fig. 6a). The xylose was almost completely consumed (>99\%) in $84 \mathrm{~h}$, which was reflected in concomitant termination of biomass, SA and AA formation. The highest SA level of $11.2 \mathrm{~g} / \mathrm{L}$ was obtained with the yield of $0.19 \mathrm{~g} / \mathrm{g}$ and $8.5 \mathrm{~g} / \mathrm{L}$ of AA was generated in the same duration. The experiment was repeated with crude xylose-rich hydrolysate derived from SCB (Fig. 6b). Hydrolysate after pre-treatment often contains inhibitors which can negatively impact the performance of microorganisms. The comparison was made to evaluate the robustness of strain in presence of fermentation inhibitor such as furfural and AA. The cell growth $\left(\mathrm{OD}_{600}: 25.3 ; 5.3 \mathrm{~g} / \mathrm{L}\right)$ was unaffected as biomass yield was almost the same in both cases. The strain accumulated $5.6 \mathrm{~g} / \mathrm{L} \mathrm{SA}$ with a yield of $0.14 \mathrm{~g} / \mathrm{g}$. In both fermentation, accumulation of substantial amount of AA $(\sim 8.5 \mathrm{~g} / \mathrm{L})$ along with SA resulted in significant reduction in $\mathrm{pH}$. Furthermore, no accumulation of xylitol was observed during fermentation, indicating active pentose phosphate pathway resulted in enhanced biomass formation.

\section{Fed-batch fermentation for SA production}

Based on the batch fermentation study, where the strain displayed excellent xylose uptake capability with simultaneous biosynthesis of SA, fed-batch fermentation was conducted to further improve SA production. The strain was evaluated in fed-batch fermentation with minimal medium without controlling $\mathrm{pH}$. The batch phase was completed in $72 \mathrm{~h}$ of fermentation, 


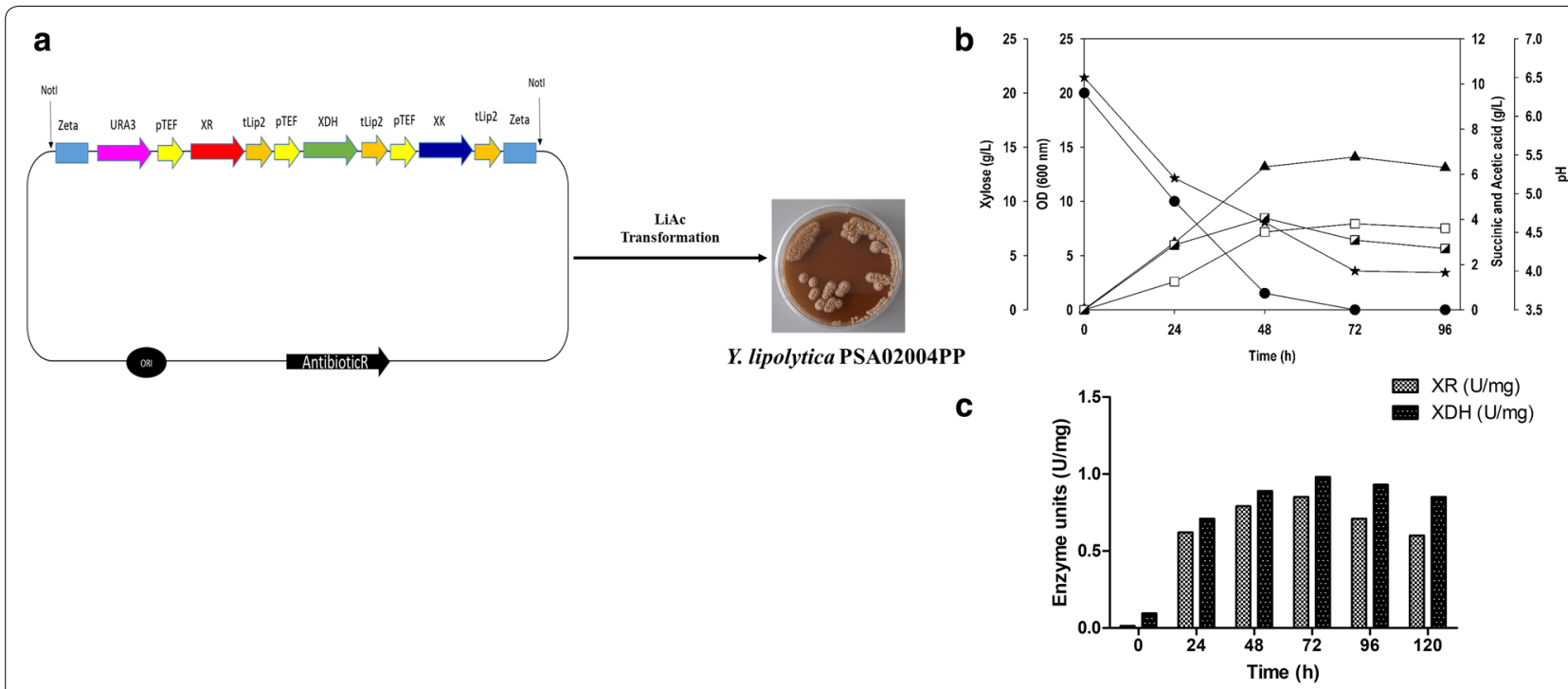

Fig. 3 a Golden Gate Assembly bearing pentose pathway genes dedicated to integration with Yarrowia lipolytica PSA02004 genome; b time-course profiles of substrate consumption, $\mathrm{OD}_{600}, \mathrm{pH}$, production of SA and AA during shake flask culture of Y. lipolytica PSA02004PP on xylose. Symbols: filled circle (xylose), filled triangle up $\left(\mathrm{OD}_{600}\right)$, empty square $(\mathrm{SA})$, semi-filled right square (AA) and filled star (pH); $\mathbf{c} X \mathrm{R}$ and XDH activity profiles during shake flask cultivation of Y. lipolytica PSA02004PP

where the initial xylose concentration was reduced to $10.3 \mathrm{~g} / \mathrm{L}$, and the strain was in exponential phase with a maximum $\mathrm{OD}_{600}$ of 32.0 , which is equivalent to $6.7 \mathrm{~g} / \mathrm{L}$ biomass concentration. The SA and AA concentration at $72 \mathrm{~h}$ were $10.8 \mathrm{~g} / \mathrm{L}$ and $11.6 \mathrm{~g} / \mathrm{L}$, respectively. The cell metabolism coupled with accumulation of these organic acids caused reduction in $\mathrm{pH}$ level to 3.9 and thereafter, $\mathrm{pH}$ was stable till the end of fermentation. The feeding was started after $72 \mathrm{~h}$ to maintain a xylose level above $10 \mathrm{~g} / \mathrm{L}$ (Fig. 7). The cell growth was continued till $108 \mathrm{~h}$, thereafter, the cell reached stationary phase and remained stable $\left(\mathrm{OD}_{600}: 50-56\right)$. Despite a low $\mathrm{pH}$, synthesis of biomass and SA was continued with a smooth rate. The highest biomass concentration of $11.8 \mathrm{~g} / \mathrm{L}$ was observed at $156 \mathrm{~h}$ of fermentation. The maximum SA concentration was $22.3 \mathrm{~g} / \mathrm{L}$, which coincided with the cell growth. The fermentation resulted in the buildup of $25.0 \mathrm{~g} / \mathrm{L} \mathrm{AA}$, a major by-product which was obtained in higher amount than the desired product SA.

\section{Discussion}

SA is a top platform chemical with multitude of industrial applications, which offers access to a wide range of products with huge commercial market. In the last two decades, significant research efforts have been devoted towards bio-based SA production. Majority of reports based on SA bioproduction are from prokaryotes with only few studies using xylose as carbon source. A. succinogenes is considered as one of the favorite candidates for SA production, due to its high acid secreting capabilities and it can uptake a wide range of sugars $[9,11]$. Even with the higher productivity, the strain is associated with the constraints such as inability to grow at low $\mathrm{pH}$ and requirement of carboxylating agent for active reductive SA pathway, which makes it unsuitable for industrial level production.

$Y$. lipolytica is well-known for the accumulation of intracellular lipids and extracellular secretion of organic acids and polyols [15]. Also, the yeast has been explored for SA production from glycerol and glucose by our research groups [17, 24, 25]. Very recently, our groups reported SA production from co-fermentation of glucose and xylose by $Y$. lipolytica [22], in which pure as well as crude glucose and xylose from SCB were utilized as carbon sources. Glucose was completely consumed by the yeast; however, large fraction of xylose (50-70\%) remained unutilized. The xylose utilization was repressed in the presence of glucose, which is in agreement with our results. Little is known about xylose metabolizing ability of $Y$. lipolytica, and there are few literature reports available on the uptake of xylose by $Y$. lipolytica which is quite contradictory. Majority of the studies indicates that $Y$. lipolytica shows a restricted uptake of xylose prior to adaptation or starvation periods. Genome mining of Y. lipolytica showed the presence of xylose pathway, however the quantitative polymerase chain reaction (qPCR) showed weak mRNA expression of $\mathrm{XDH}$ gene (YALIOE12463), indicating the hypothesis that weak expression of $\mathrm{XDH}$ is the limiting factor [26]. 


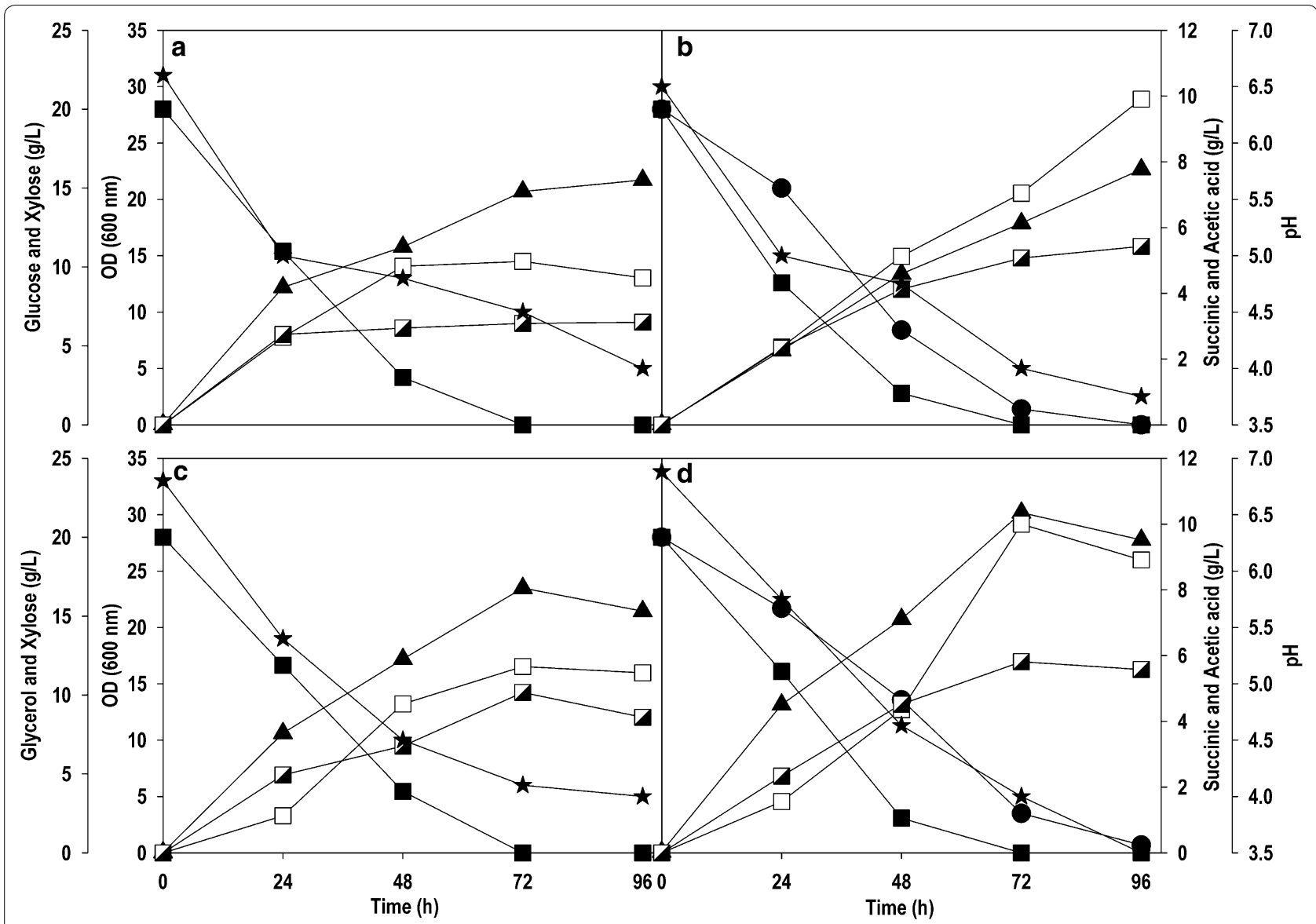

Fig. 4 Time-course profiles of substrate consumption, $\mathrm{OD}_{600}, \mathrm{pH}$, production of SA and AA during shake flask culture of Y. lipolytica PSA02004PP on: a glucose, $\mathbf{b}$ glucose + xylose, c glycerol and $\mathbf{d}$ glycerol + xylose. Symbols: filled square (glucose or glycerol), filled circle (xylose), filled triangle up $\left(\mathrm{OD}_{600}\right)$, empty square $(\mathrm{SA})$, semi-filled right square $(\mathrm{AA})$ and filled star $(\mathrm{pH})$

According to Rodriguez et al. [27], xylose pathway is present in the yeast, but it was poorly expressed due to cryptic genetic circuits controlling expression of the key enzymes. It was found that overexpression of endogenous XDH (YALIOE12463) and XK (YALIOF10293) in Y. lipolytica Po1f strain under the control of UAS1B8-TEF ${ }_{\text {min }}$ promoter resulted in cell growth on xylose. In the same year, Ledesma-Amaro et al. engineered Y. lipolytica by introducing XR and XDH from $S$. stipitis, which serves as a model organism for xylose metabolism [28]. They observed that overexpression of XR and XDH is insufficient to enable growth on xylose, and additional overexpression of XK allowed identical growth to wild-type strain. The engineered strain was able to produce lipids and citric acid utilizing xylose as a sole carbon source. The same group also demonstrated the utilization of xylose-rich agave bagasse hydrolysate by $Y$. lipolytica harboring $X R, X D H$ and $X K$ gene cassette under the control of TEF promoter [29].
In the present study, three enzymes, XR, XDH and XK, were overexpressed under the control of constitutive TEF promoter in Y. lipolytica PSA02004. The metabolic pathway for xylose utilization and SA production by recombinant Y. lipolytica PSA02004PP is depicted in Fig. 1. The control strain was unable to grow on xylose as the sole carbon source, but it was able to transform xylose to xylitol in the presence of co-substrates such as glucose and glycerol (Fig. 2). Similar results were obtained by Ledesma-Amaro et al. [28] and Prabhu et al. [30] where biotransformation of xylose into xylitol was observed during co-fermentations with glucose/glycerol. The introduction of xylose pathway resulted in a marked change in metabolism. The recombinant strain was able to grow $\left(\mathrm{OD}_{600}: 14.1\right)$ on xylose as the sole carbon source, as well as accumulated SA $(3.8 \mathrm{~g} / \mathrm{L})$, and generated AA $(4.1 \mathrm{~g} / \mathrm{L})$ as a by-product (Fig. 3b). In case of co-fermentation with xylose and glucose/glycerol, the xylitol formation was not observed and SA production increased in comparison to the control strain, which is supported by the high $\mathrm{XDH}$ 

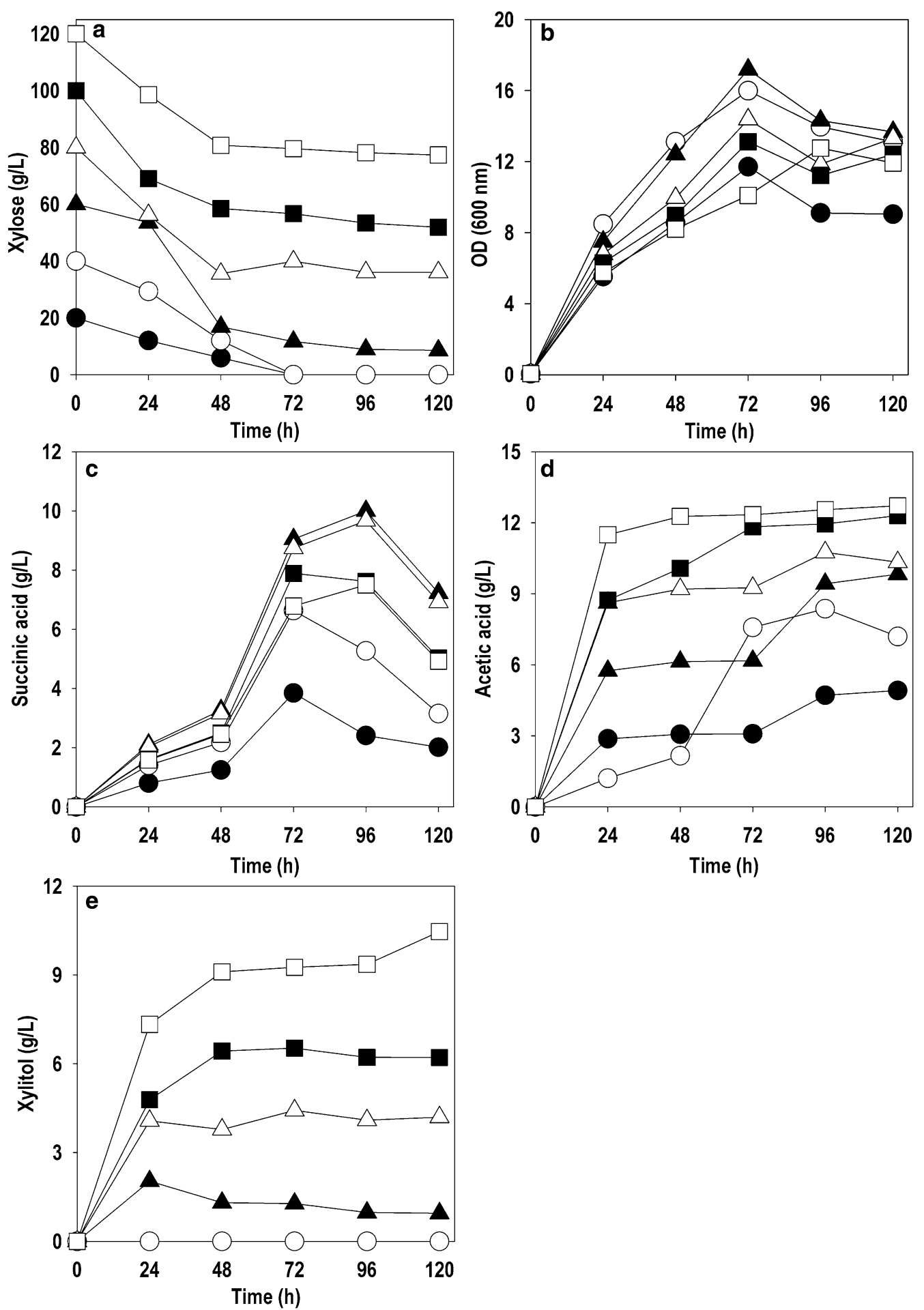

Fig. 5 Time course profile of $Y$. lipolytica PSA02004PP at different xylose levels a substrate consumption, b OD ${ }_{600}$, c SA, d AA, e Xylitol. Symbols: filled circle (20 g/L), empty circle (40 g/L), filled triangle up (60 g/L), empty triangle up $(80 \mathrm{~g} / \mathrm{L})$, filled square $(100 \mathrm{~g} / \mathrm{L})$ and empty square $(120 \mathrm{~g} / \mathrm{L})$ 

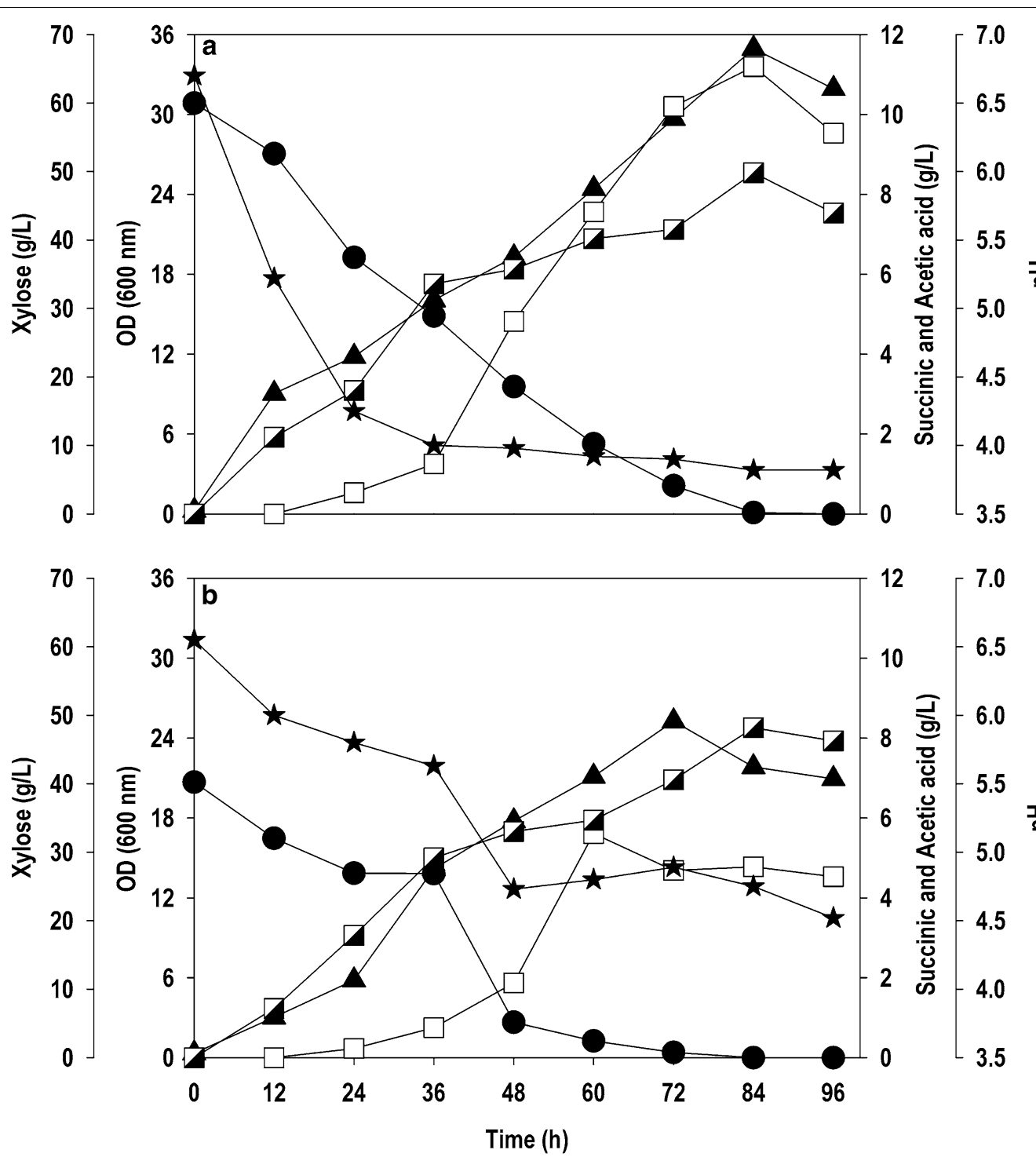

12

10

Fig. 6 Batch cultivation of Y. lipolytica PSA02004PP in bioreactor using a pure xylose, b xylose-rich hydrolysate derived from sugarcane bagasse. Symbols: filled circle (xylose), filled triangle up $\left(\mathrm{OD}_{600}\right)$, empty square $(\mathrm{SA})$, semi-filled right square $(\mathrm{AA})$, and filled star $(\mathrm{pH})$

activity during the exponential growth phase (Fig. 4b, d). Walfridsson et al. [31] reported that high XDH to XR ratio resulted in no xylitol accumulation and high ethanol formation rate in recombinant Saccharomyces cerevisiae strain integrated with multi-copy gene of $x y l 2$ encoding xylitol dehydrogenase. The carbon catabolite repression was observed with xylose and its rapid consumption began after $48 \mathrm{~h}$ when glucose/glycerol was largely assimilated. This is in agreement with results obtained by Ledesma-Amaro et al. [28] and Ong et al. [22]. In the current study, we investigated the impact of initial xylose levels on Y. lipolytica using the minimal medium, and it was observed a substrate inhibition beyond $60 \mathrm{~g} / \mathrm{L}$. The xylose was completely utilized until $40 \mathrm{~g} / \mathrm{L}$ and with further increase in the initial xylose concentration, the amount of residual xylose continuously elevated (Fig. 5a). The substrate inhibition phenomenon also negatively affected SA production (Fig. 5c). The xylitol accumulation was detected at higher xylose concentrations indicating overflow metabolism (Fig. 5e). XR and XDH enzymes are dependent on $\mathrm{NAD}(\mathrm{P}) \mathrm{H}$ and $\mathrm{NAD}^{+}$, respectively. At high concentration of xylose, redox imbalance will be provoked and results in xylitol accumulation [32]. Similar trend was observed by Ledesma-Amaro et al. [28]. 

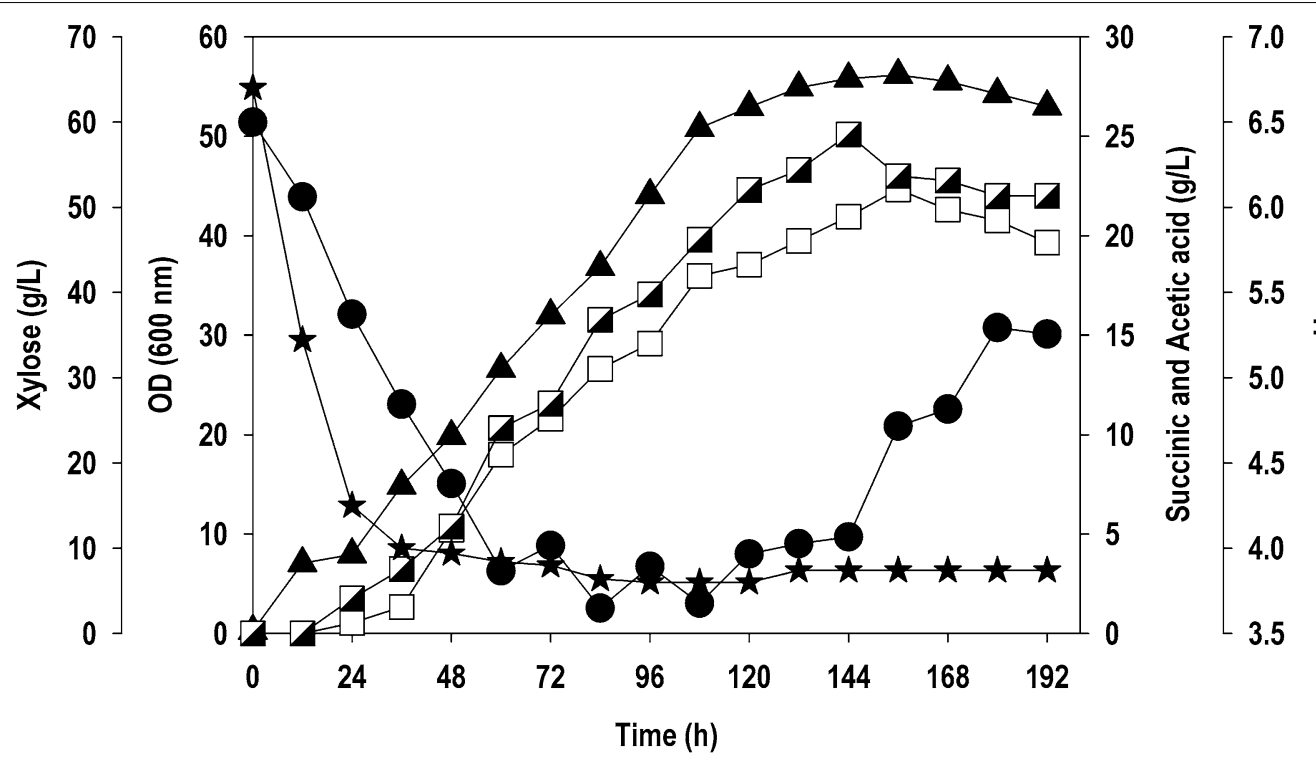

Fig. 7 Fed-batch kinetics of xylose uptake, cell growth, product formation and pH during Y. lipolytica PSA02004PP fermentation in bioreactor. Symbols: filled circle (xylose), filled triangle up $\left(\mathrm{OD}_{600}\right)$, empty square $(\mathrm{SA})$, semi-filled right square $(\mathrm{AA})$, and filled star $(\mathrm{pH})$

In their study, xylose was completely consumed at up to $30 \mathrm{~g} / \mathrm{L}$. However, Y. lipolytica was unable to consume all the xylose at initial concentration $60-90 \mathrm{~g} / \mathrm{L}$, and $15-70 \%$ of xylose was left unconsumed at these concentrations along with xylitol accumulation. Similar pattern of substrate inhibition was observed by Salvachúa et al. [33] with $A$. succinogenes beyond $60 \mathrm{~g} / \mathrm{L}$ xylose concentration. The strain resulted in maximum of $48 \mathrm{~g} / \mathrm{L}$ SA with $80 \mathrm{~g} / \mathrm{L}$ xylose concentration.

The scale-up of data from shake flask to bioreactor level improved SA synthesis from $3.8 \mathrm{~g} / \mathrm{L}$ to $11.2 \mathrm{~g} / \mathrm{L}$ (Fig. 6a). The results obtained with crude xylose from SCB hydrolysate were highly encouraging. The yeast grew robustly $\left(\mathrm{OD}_{600}: 25.3\right)$ on crude xylose despite the presence of AA and furfural at significant levels (Fig. 6b), in accordance with previous reports on agave hydrolysates [29]. The resultant SA concentration was $5.6 \mathrm{~g} / \mathrm{L}$ with a yield of $0.14 \mathrm{~g} / \mathrm{g}$, which is similar to those obtained with pure xylose $(0.19 \mathrm{~g} / \mathrm{g})$. The fed-batch cultivation of recombinant strain further improved the performance and yielded a biomass and SA concentration of 11.8 and $22.3 \mathrm{~g} / \mathrm{L}$, respectively, at $156 \mathrm{~h}$ (Fig. 7). Besides cell growth and SA synthesis, AA was continuously accumulated up to $25.0 \mathrm{~g} / \mathrm{L}$. These results indicate that more carbon flux is diverted towards by-product formation resulting in reduced SA production, however the strain showed resistance at lower $\mathrm{pH}$ condition $(<4.0)$. Cui et al. [17] reported excessive production of AA in glycerol fermentation using Y. lipolytica PGC1003 strain. Hyperaccumulation of AA might be due to the imbalance between the flux of glycolysis and TCA cycle, which interrupts the cell growth and also affects the cell metabolism [34]. Two different approaches can be employed to curb AA formation: disrupting pathways leading to AA formation, and the second one is diverting AA towards SA production. The AA produced, an undesirable product, can be combined with xylose utilization for SA production and this co-fermentation will be beneficial for efficient utilization of lignocellulosic hydrolysate containing substantial amount of AA [35-37]. In order to understand the robustness of the recombinant Y. lipolytica PSA02004PP strain to withstand adverse condition such as low $\mathrm{pH}$, the $\mathrm{pH}$ was not controlled in fermentations carried out in this study. The strain was able to grow and biosynthesize SA continuously even after significant reduction in $\mathrm{pH}$, which shows its robustness and flexibility. The recovery and purification of SA is an obstacle for commercial production [8]. The advantage at lower $\mathrm{pH}$ is that most of the product fraction will be in acidic form (rather than dissociated form), resulting in simple and cost-effective downstream processes [38]. Table 1 shows SA production by different microorganisms using xylose as carbon source. The SA titers obtained in current work are comparable to the data available in literature, making it competitive; however, the yield and volumetric productivity were lower. It was very evident that most of the bacteria such as $A$. succinogenes, B. succiniciproducens and E. coli with inherited xylose uptake metabolism have shown better SA production capabilities using xylose as a sole carbon source. Our work did not make use of any alkali or 
$\mathrm{pH}$ regulators to control/maintain the $\mathrm{pH}$ unlike other reports in Table 1. Although the current SA production would not be practical for commercial use, these results still suggest great potential for this engineered $Y$. lipolytica strain in the production of SA from xylose.

\section{Conclusions}

The realization of biological SA production is highly dependent on utilization of low-cost renewable resources. The bio-based SA production from LCB can be a promising strategy as compared to the petrochemical route. The valorization of xylose is imperative for profitable and economical LCB-based SA production. $Y$. lipolytica can robustly metabolize a large variety of substrates including hydrophilic (glucose, glycerol, ethanol, acetate) as well as hydrophobic carbon sources (alkanes, fatty acids, oils), but it is unable to consume xylose, second major sugar in LCB. The current study made use of rational metabolic engineering strategy to develop a xylose-utilizing $Y$. lipolytica strain for manufacturing SA. The experimental results reported in this study demonstrate the promising potential of engineered strain to accumulate SA from pure as well as crude xylose. The accumulation of SA at low $\mathrm{pH}$ gives further advantage. In our knowledge, this is the first reported study utilizing metabolically engineered Y. lipolytica for SA production from xylose. The work serves as a proof of concept, and it creates room for further improvements for upcycling of agricultural residues into SA. In order to enhance the performance required for commercial production of SA, development of novel metabolic engineering strategies and process engineering work are required.

\section{Methods}

\section{Materials used in this study}

All chemicals used in this study were of analytical grade and purchased from Sigma Aldrich (USA) and Fisher scientific unless stated otherwise. All restriction enzymes, DNA ligase and Q5 Taq DNA polymerase used for the PCR and cloning were purchased from New England Biolabs (NEB) (USA). The xylose-rich lignocellulosic hydrolysate from SCB with following composition was obtained from Nova Pangea Technologies, UK. The composition of the hydrolysate was as follows $(\mathrm{g} / \mathrm{L})$ : xylose, 42.8; glucose, 2.8; arabinose; acetic acid, $1.8 \mathrm{~g} / \mathrm{L}$; furfural $<1.0$.

\section{Microorganism, culture maintenance and inoculum preparation}

The current study made use of strain originated from adaptive evolution of engineered Y. lipolytica PSA02004 with deletion of $Y l s d h 5$ gene encoding a sub-unit of succinate dehydrogenase [18]. The recombinant $Y$. lipolytica strain was preserved in $20 \%$ glycerol $(\mathrm{v} / \mathrm{v})$ at $-80{ }^{\circ} \mathrm{C}$ and maintained on a petri dish containing YPD agar medium ( $1 \%$ yeast extract, $2 \%$ peptone, $2 \%$ dextrose and $2 \%$ agar) at $\mathrm{pH} 7.0$ and $30^{\circ} \mathrm{C}$. The seed culture was grown in a 250$\mathrm{mL}$ Erlenmeyer flask containing $50 \mathrm{~mL}$ minimal medium (see section Submerged cultivations in shake flask). The flasks for seed culture were inoculated by transferring a loopful of 48-h culture grown on a YPD plate. The final $\mathrm{pH}$ of the medium prior to sterilization was adjusted to 6.8. Cultivation was carried out for $24 \mathrm{~h}$ at $30^{\circ} \mathrm{C}$ on a rotary shaker at an agitation speed of $250 \mathrm{rpm}$.

\section{Cloning and expression of heterologous xylose assimilation gene in $Y$. lipolytica strain}

Escherichia coli (DH5 $\alpha)$ strain was used for cloning and plasmid propagation. The strain was cultivated in the lysogeny broth (LB) liquid medium at $37{ }^{\circ} \mathrm{C}$. The gene encoding xylose reductase (XR) (YALIOD07634), xylitol dehydrogenase (XDH) (YALIOE12463) and xylulokinase (XK) (YALIF10923) were extracted from the genome of Po1d using the appropriate primers (Additional file 1: Table S1) and the Golden Gateway (GG) assembly was constructed according to former studies $[39,40]$. The GG was constructed with a scaffold of three genes comprising three transcription units and selection marker, flanked with integration targeting sequences, constructed on a destination vector backbone. Each gene was flanked with $396 \mathrm{nt}$ of TEF promoter and $122 \mathrm{nt}$ of Lip2 terminator sequences, both native to Y. lipolytica. URA3 (1289 nt) gene was used as selection marker in this assembly. Random integrations in $Y$. lipolytica PSA02004 were driven through zeta sequences (305 nt and $395 \mathrm{nt}$ for UP and DOWN, respectively). The expression vector was linearized using NotI enzyme and gel purified before transformation in Y. lipolytica. The overexpression cassette was transformed in the genome of Y. lipolytica using lithium acetate method described by Le Dall et al. [41]. The transformants were selected on YNBUra plates, the genomic DNA was isolated using the protocol developed by Lõoke et al. [42], and the positive transformants were identified with PCR. All the plasmids and strains used in this study are listed in Additional file 1: Table S2.

\section{Submerged cultivations in shake flask}

The minimal medium used for fermentation had the following composition: xylose, $20 \mathrm{~g} / \mathrm{L}$; yeast nitrogen base (YNB), $1.7 \mathrm{~g} / \mathrm{L} ; \mathrm{NH}_{4} \mathrm{Cl}, 1.5 \mathrm{~g} / \mathrm{L}$. The medium was prepared in $50 \mathrm{mM}$ phosphate buffer. In case of co-fermentation with two carbon sources, each one was used at a level of $20 \mathrm{~g} / \mathrm{L}$. The initial $\mathrm{pH}$ was adjusted to 6.5-6.8 before inoculation by using $5 \mathrm{~N} \mathrm{NaOH}$. The submerged cultivations were carried out in $500-\mathrm{mL}$ shake flasks containing $100 \mathrm{~mL}$ working volume. The flasks were 
Table 1 Xylose-based succinic acid production by various microorganisms

\begin{tabular}{|c|c|c|c|c|c|c|c|c|c|}
\hline \multirow[t]{2}{*}{ Organism } & \multirow{2}{*}{$\begin{array}{l}\text { Fermentation } \\
\text { mode }\end{array}$} & \multirow{2}{*}{$\begin{array}{l}\text { Feedstock } \\
\text { (xylose } \\
\text { fraction) }\end{array}$} & \multirow[t]{2}{*}{ Other sugars } & \multirow{2}{*}{$\begin{array}{l}\text { Xylose } \\
\text { consumed } \\
\text { (g/L) }\end{array}$} & \multicolumn{3}{|c|}{ Succinic acid } & \multirow{2}{*}{$\begin{array}{l}\text { Main } \\
\text { by-products } \\
\text { (g/L) }\end{array}$} & \multirow[t]{2}{*}{ Reference } \\
\hline & & & & & Titer (g/L) & Yield $^{\mathrm{a}}(\mathrm{g} / \mathrm{g})$ & $\begin{array}{l}\text { Productivity } \\
\text { (g/L/h) }\end{array}$ & & \\
\hline $\begin{array}{l}\text { A. succinogenes } \\
130 Z\end{array}$ & Batch & SSL (72.6\%) & $\begin{array}{l}\text { Galactose } \\
(12.2 \%), \\
\text { glucose } \\
(10.9 \%), \text { man- } \\
\text { nose }(4.2 \%), \\
\text { arabinose } \\
(0.1 \%)\end{array}$ & 30.2 & 27.4 & 0.70 & 0.45 & $\begin{array}{c}\mathrm{FA}(8.8) \mathrm{AA} \\
\quad(12.6)\end{array}$ & {$[45]$} \\
\hline $\begin{array}{l}\text { B. succinicip- } \\
\text { roducens } \\
\text { JF4016 }\end{array}$ & Batch & SSL (72.6\%) & $\begin{array}{l}\text { Galactose } \\
(12.2 \%), \\
\text { glucose } \\
(10.9 \%), \text { man- } \\
\text { nose }(4.2 \%), \\
\text { arabinose } \\
(0.1 \%)\end{array}$ & 25.0 & 26.0 & 0.76 & 0.55 & $\begin{array}{c}\mathrm{FA}(3.3) \mathrm{AA} \\
(8.3)\end{array}$ & {$[45]$} \\
\hline $\begin{array}{l}\text { A. succinogenes } \\
130 Z\end{array}$ & Batch & Pure xylose & - & 22.00 & 14.2 & 0.64 & 0.67 & - & {$[46]$} \\
\hline $\begin{array}{l}\text { A. succinogenes } \\
130 Z\end{array}$ & Batch & $\operatorname{SCB}(-)$ & - & 52.00 & 22.5 & 0.43 & 1.01 & - & {$[46]$} \\
\hline $\begin{array}{l}\text { E. coli recombi- } \\
\text { nant SD121 }\end{array}$ & Batch & $\begin{array}{l}\text { Pretreated } \\
\text { mother liquor } \\
(51.7 \%)\end{array}$ & $\begin{array}{l}\text { Arabinose } \\
\text { (10-15\%), } \\
\text { glucose } \\
(8-10 \%), \\
\text { galactose } \\
(8-10 \%)\end{array}$ & 37.01 & 52.1 & 0.63 & 0.62 & $\mathrm{AA}(10)$ & {$[47]$} \\
\hline $\begin{array}{c}\text { A. succinogenes } \\
\text { CICC } 11014\end{array}$ & Batch & $\begin{array}{l}\text { Corncob } \\
\text { hydrolysate } \\
(77.3 \%)\end{array}$ & $\begin{array}{l}\text { Glucose }(2.8 \%), \\
\text { arabinose } \\
(12.9 \%), \\
\text { cellobiose } \\
(7.0 \%)\end{array}$ & 38.1 & 23.64 & 0.58 & 0.49 & - & {$[48]$} \\
\hline E. coli BA204 & $\begin{array}{l}\text { Batch dual } \\
\text { phase }\end{array}$ & $\begin{array}{l}\text { Pretreated } \\
\text { cornstalk } \\
(80.7 \%)\end{array}$ & $\begin{array}{l}\text { Glucose } \\
\text { (13.5\%) }\end{array}$ & 8.1 & 11.13 & 1.03 & 0.70 & $\mathrm{AA}(2.5)$ & [49] \\
\hline E. coli BA408 & Batch & $\begin{array}{l}\text { Corn stalk } \\
\text { hydrolysate } \\
(81.6 \%)\end{array}$ & $\begin{array}{l}\text { Glucose }(9.5 \%) \text {, } \\
\text { arabinose } \\
(3.5 \%)\end{array}$ & 23 & 23.1 & 0.85 & 0.24 & $\mathrm{AA}(<0.5)$ & {$[50]$} \\
\hline $\begin{array}{l}\text { B. succinicip- } \\
\text { roducens } \\
\text { JF4016 }\end{array}$ & Batch & Pure xylose & - & 7.67 & 4.6 & 0.60 & 0.80 & $\begin{array}{c}\mathrm{FA}(1.9), \mathrm{AA} \\
(2.6)\end{array}$ & [51] \\
\hline $\begin{array}{l}\text { A. succinogenes } \\
130 Z\end{array}$ & Batch & $\begin{array}{c}\text { Corn stover } \\
(73.4 \%)\end{array}$ & $\begin{array}{l}\text { Glucose } \\
(10.1 \%), \\
\text { galactose } \\
(4.9 \%), \\
\text { arabinose } \\
(11.6 \%)\end{array}$ & 55.4 & 42.8 & 0.74 & 1.27 & $\begin{array}{l}\text { FA }(-), A A \\
(-)\end{array}$ & {$[33]$} \\
\hline $\begin{array}{l}\text { Y. lipolytica } \\
\text { PSA02004PP }\end{array}$ & Batch & Pure xylose & - & 60 & 11.2 & 0.19 & 0.13 & $A A(8.5)$ & This study \\
\hline $\begin{array}{l}\text { Y. lipolytica } \\
\text { PSA02004PP }\end{array}$ & Batch & SCB (90.5\%) & $\begin{array}{l}\text { Glucose }(6.0 \%) \text {, } \\
\text { arabinose } \\
(3.6 \%)\end{array}$ & 37.8 & 5.6 & 0.13 & 0.09 & $A A(8.3)$ & This study \\
\hline $\begin{array}{l}\text { Y. lipolytica } \\
\text { PSA02004PP }\end{array}$ & Fed-batch & Pure xylose & - & 150 & 22.3 & 0.15 & 0.14 & $A A(25)$ & This study \\
\hline
\end{tabular}

In all the studies mentioned above except current work, $\mathrm{pH}$ was controlled/maintained either by automatic addition of alkali agents or supplementing culture medium with $\mathrm{pH}$ regulators

Italic values represent the result obtained in this study

$A A$ acetic acid, $F A$ formic acid, SSL-spent sulphite liquor

a The yield is calculated on the basis of total sugars consumed 
inoculated with fresh inoculum at $\mathrm{OD}_{600}$ of 0.1 and kept at $30{ }^{\circ} \mathrm{C}$ under constant shaking at $250 \mathrm{rpm}$ on a rotary shaker.

\section{Measurement of xylose reductase (XR) and xylitol dehydrogenase (XDH) activities}

For measuring the enzymatic activities, cell-free extract was prepared. Initially, the cells were harvested by centrifugation at $8000 \mathrm{~g}$ and $4{ }^{\circ} \mathrm{C}$ for $10 \mathrm{~min}$. The cell pellet was then washed twice with $50 \mathrm{mM}$ phosphate buffer (pH 7.2) and resuspended in the buffer. The cell disruption was performed in homogenizer by mixing the abovementioned cells with $0.5 \mathrm{~g}(0.3 \mathrm{~mm})$ glass beads and vortexed for $10 \mathrm{~min}$. The homogenized mixture was centrifuged at $8,000 \mathrm{~g}$ and $4{ }^{\circ} \mathrm{C}$ for $10 \mathrm{~min}$, the supernatant was collected and used for quantifying enzyme activities. The protein concentration was determined by the Bradford method [43].

The activities of xylose reductase (XR) and xylitol dehydrogenase $(\mathrm{XDH})$ were measured using a UV spectrophotometer (Jenway 6310, UK). The molar extinction coefficient of NADPH and NAD ${ }^{+}$used for calculation is $6,220 \mathrm{~m}^{-1} \mathrm{~cm}^{-1}$. The XR activity was measured by the reduction of the coenzyme NADPH at $30^{\circ} \mathrm{C}$ in a reaction medium consisting of $0.17 \mathrm{mM}$ NADPH, $0.17 \mathrm{M}$ xylose, $0.25 \mathrm{mg}$ cell extract, and the final volume was made up to $0.5 \mathrm{~mL}$ using $0.1 \mathrm{M}$ phosphate buffer. One unit of XR enzyme activity was defined as the amount of enzyme that catalyzed the oxidation of $1 \mu \mathrm{mol}$ of NADPH per minute at $30^{\circ} \mathrm{C}$. The quantification of XDH activity was based on reduction of the coenzyme $\mathrm{NAD}^{+}$at $30{ }^{\circ} \mathrm{C}$. For XDH measurement, the reaction mixture consists of $1.5 \mathrm{mM} \mathrm{NAD}^{+}, 0.15 \mathrm{M}$ xylitol, $0.25 \mathrm{mg}$ cell extract with a total volume of $0.5 \mathrm{~mL}$ made up by $0.1 \mathrm{M}$ Tris buffer. One unit of XDH was defined as the amount of enzyme catalyzing the oxidation of $1 \mu \mathrm{mol}$ of $\mathrm{NAD}^{+}$per minute at $30^{\circ} \mathrm{C}$ [44].

\section{Bioreactor studies}

The batch experiments were performed in a 2.5-L benchtop bioreactor (Electrolab Bioreactors, UK) with 1.0-L working volume. The minimal medium with $60 \mathrm{~g} / \mathrm{L}$ xylose was used for running bioreactor experiments. In case of lignocellulosic hydrolysate, the xylose concentration was $40 \mathrm{~g} / \mathrm{L}$. The temperature, agitation speed and aeration rate were controlled at $30{ }^{\circ} \mathrm{C}, 600 \mathrm{rpm}$ and $2.0 \mathrm{~L} / \mathrm{min}$, respectively. The starting $\mathrm{pH}$ was 6.8 , and it remained uncontrolled during the fermentation. For fedbatch fermentations, the residual xylose concentration was maintained at or above $10 \mathrm{~g} / \mathrm{L}$ with concentrated feed containing $500 \mathrm{~g} / \mathrm{L}$ xylose and $5 \mathrm{~g} / \mathrm{L}$ yeast extract.

\section{Analytical methods}

The samples were withdrawn periodically and analyzed for $\mathrm{OD}_{600}, \mathrm{pH}$, residual glucose, glycerol, xylose, xylitol, SA and AA. Cell growth was quantified by measuring the optical density at $600 \mathrm{~nm}$ wavelength in a $1-\mathrm{mm}$ path-length cuvette using a double-beam spectrophotometer (Jenway 6310, UK). One unit of absorbance at $600 \mathrm{~nm}$ corresponded to a cell dry weight (CDW) of $0.21 \mathrm{~g} / \mathrm{L}$. The concentrations of glucose, glycerol, xylose, xylitol, SA and AA were measured by high-performance liquid chromatography (Agilent Technologies 1200 series, USA). The supernatants obtained by centrifugation of the culture samples at $10,000 \mathrm{~g}$ for $10 \mathrm{~min}$ were filtered through a 0.22- $\mu$ m PVDF membrane (Sartorius, Germany)) and eluted using Rezex ROA-Organic Acid $\mathrm{H}+\left(\right.$ Phenomenex, USA) column at $60{ }^{\circ} \mathrm{C}$ attached with refractive index detector (RID) and diode array detector (DAD). The mobile phase and flow rate were $0.5 \mathrm{mM}$ $\mathrm{H}_{2} \mathrm{SO}_{4}$ and $0.4 \mathrm{~mL} / \mathrm{min}$, respectively. All measurements were conducted in triplicates and the values were averaged. The standard deviation was no more than $10 \%$.

\section{Supplementary information}

Supplementary information accompanies this paper at https://doi. org/10.1186/s13068-020-01747-3.

Additional file 1: Table S1. Primers used in this study. Table S2. List of Plasmids and strain used in this study.

\section{Acknowledgements}

We are grateful to BBSRC, Innovate UK and Department of Biotechnology, India for funding the vWa Project (Grant R1954CCE). The authors express gratitude to Cranfield University for providing facilities for conducting experiments. We acknowledge our industrial partner, Nova Pangaea Technologies for providing xylose rich SCB hydrolysate for this work.

\section{Authors' contributions}

AAP carried out all the experimental work, analyzed the data. VK analyzed the data and wrote the manuscript. FC and VKT were involved in proofreading the manuscript. CSKL and RL provided useful suggestions for experimental design and revised the manuscript critically. All authors read and approved the final manuscript.

\section{Funding}

The work is funded by the BBSRC, Innovate UK and Department of Biotechnology, India (Grant R1954CCE). The funders had no role in study design, data collection and analysis, decision to publish, nor preparation of the article.

\section{Availability of data and materials}

All data generated or analyzed during this study are included in the manuscript.

Ethics approval and consent to participate

Not applicable.

Consent for publication

Not applicable.

Competing interests

The authors declare that they have no competing interests. 


\section{Author details}

1 School of Water, Energy and Environment, Cranfield University, Cranfield MK43 OAL, UK. ${ }^{2}$ Department of Bioengineering and Imperial College Centre for Synthetic Biology, Imperial College London, London SW7 2AZ, UK. ${ }^{3}$ School of Energy and Environment, City University of Hong Kong, Kowloon Tong, Kowloon, Hong Kong. ${ }^{4}$ Biorefining and Advanced Materials Research Centre, Scotland's Rural College (SRUC), Edinburgh, UK.

Received: 27 March 2020 Accepted: 5 June 2020 Published online: 27 June 2020

\section{References}

1. Chu S, Majumdar A. Opportunities and challenges for a sustainable energy future. Nature. 2012;298:294-303.

2. Kwak S, Jo JH, Yun EJ, Jin YS, Seo JH. Production of biofuels and chemicals from xylose using native and engineered yeast strains. Biotechnol Adv. 2019;37:271-83.

3. Zhao Z, Xian M, Liu M, Zhao G. Biochemical routes for uptake and conversion of xylose by microorganisms. Biotechnol Biofuels. 2020;13:21.

4. Kwak S, Jin Y-S. Production of fuels and chemicals from xylose by engineered Saccharomyces cerevisiae: a review and perspective. Microb Cell Fact. 2017;16:82

5. Takkellapati S, Li T, Gonzalez MA. An overview of biorefinery-derived platform chemicals from a cellulose and hemicellulose biorefinery. Clean Technol Environ Policy. 2018;20:1615-30.

6. Babaei M, Rueksomtawin Kildegaard K, Niaei A, Hosseini M, Ebrahimi S, Sudarsan S, et al. Engineering oleaginous yeast as the host for fermentative succinic acid production from glucose. Front Bioeng Biotechnol. 2019;7:361.

7. Chinthapalli R, Iffland K, Aeschelmann F, Raschka A, Carus M. Succinic acid: new bio-based building block with a huge market and environmental potential? Nova-Institut GmbH. http://www.bio-based.eu/reports/.

8. Cheng KK, Zhao XB, Zeng J, Wu RC, Xu YZ, Liu DH, et al. Downstream processing of biotechnological produced succinic acid. Appl Microbiol Biotechnol. 2012;95:841-50.

9. Pateraki C, Patsalou M, Vlysidis A, Kopsahelis N, Webb C, Koutinas AA, et al. Actinobacillus succinogenes: Advances on succinic acid production and prospects for development of integrated biorefineries. Biochem Eng J. 2016:112:285-303.

10. Stylianou E, Pateraki C, Ladakis D, Cruz-Fernández M, Latorre-Sánchez M, Col $C$, et al. Evaluation of organic fractions of municipal solid waste as renewable feedstock for succinic acid production. Biotechnol Biofuels. 2020;13:72.

11. Dessie W, Xin F, Zhang W, Jiang Y, Wu H, Ma J, et al. Opportunities, challenges, and future perspectives of succinic acid production by Actinobacillus succinogenes. Appl Microbiol Biotechnol. 2018;102:9893-910.

12. Jansen MLA, van GulikWM. Towards large scale fermentative production of succinic acid. Curr Opin Biotechnol. 2014;30:190-7.

13. Cavallo E, Charreau H, Cerrutti P, Foresti ML. Yarrowia lipolytica: a model yeast for citric acid production. FEMS Yeast Res. 2017. https://doi.org/10.1093/ femsyr/fox084.

14. Abdel-Mawgoud AM, Markham KA, Palmer CM, Liu N, Stephanopoulos G, Alper HS. Metabolic engineering in the host Yarrowia lipolytica. Metab Eng. 2018;50:192-208.

15. Liu HH, Ji XJ, Huang H. Biotechnological applications of Yarrowia lipolytica: past, present and future. Biotechnol Adv. 2015;33(8):1522-46.

16. Egermeier M, Russmayer $\mathrm{H}$, Sauer M, Marx H. Metabolic flexibility of Yarrowia lipolytica growing on glycerol. Front Microbiol. 2017;8:49.

17. Cui Z, Gao C, Li J, Hou J, Lin CSK, Qi Q. Engineering of unconventional yeast Yarrowia lipolytica for efficient succinic acid production from glycerol at low pH. Metab Eng. 2017;42:126-33.

18. Yang X, Wang H, Li C, Lin CSK. Restoring of glucose metabolism of engineered Yarrowia lipolytica for succinic acid production via a simple and efficient adaptive evolution strategy. J Agric Food Chem. 2017:65:4133-9.

19. Ledesma-Amaro R, Nicaud JM. Metabolic engineering for expanding the substrate range of Yarrowia lipolytica. Trends Biotechnol. 2016;34(10):798-809.

20. Cheng KK, Zhao XB, Zeng J, Zhang JA. Biotechnological production of succinic acid: current state and perspectives. Biofuels Bioprod Biorefin. 2012;6:302-18.
21. Nghiem N, Kleff S, Schwegmann S. Succinic acid: technology development and commercialization. Fermentation. 2017;3:26.

22. Ong KL, Li C, Li X, Zhang Y, XU J, Lin CSK. Co-fermentation of glucose and xylose from sugarcane bagasse into succinic acid by Yarrowia lipolytica. Biochem Eng J. 2019;148:108-15.

23. Gao C, Yang X, Wang H, Rivero CP, Li C, Cui Z, et al. Robust succinic acid production from crude glycerol using engineered Yarrowia lipolytica. Biotechno Biofuels. 2016;9:179.

24. Li C, Yang X, Gao S, Wang H, Lin CSK. High efficiency succinic acid production from glycerol via in situ fibrous bed bioreactor with an engineered Yarrowia lipolytica. Bioresour Technol. 2017;225:9-16.

25. Li C, Gao S, Li X, Yang X, Lin CSK. Efficient metabolic evolution of engineered Yarrowia lipolytica for succinic acid production using a glucose-based medium in an in situ fibrous bioreactor under low-pH condition. Biotechnol Biofuels. 2018;11:236.

26. Spagnuolo M, Hussain MS, Gambill L, Blenner M. Alternative substrate metabolism in Yarrowia lipolytica. Microbiol: Front; 2018.

27. Rodriguez GM, Hussain MS, Gambill L, Gao D, Yaguchi A, Blenner M. Engineering xylose utilization in Yarrowia lipolytica by understanding its cryptic xylose pathway. Biotechnol Biofuels. 2016:9:149.

28. Ledesma-Amaro R, Lazar Z, Rakicka M, Guo Z, Fouchard F, Le Coq AMC, et al. Metabolic engineering of Yarrowia lipolytica to produce chemicals and fuels from xylose. Metab Eng. 2016;38:115-24.

29. Niehus X, Crutz-Le Coq AM, Sandoval G, Nicaud JM, Ledesma-Amaro R. Engineering Yarrowia lipolytica to enhance lipid production from lignocellulosic materials. Biotechnol Biofuels. 2018;11:11.

30. Prabhu AA, Thomas DJ, Ledesma-Amaro R, Leeke GA, Medina A, VerheeckeVaessen C, Coulon F, Agrawal D, Kumar V. Biovalorisation of crude glycerol and xylose into xylitol by oleaginous yeast Yarrowia lipolytica. Microb Cell Fact. 2020. https://doi.org/10.1186/s12934-020-01378-1.

31. Walfridsson M, Anderlund M, Bao X, Hahn-Hägerdal B. Expression of different levels of enzymes from the Pichia stipitis XYL1 and XYL2 genes in Saccharomyces cerevisiae and its effects on product formation during xylose utilisation. Appl Microbiol Biotechnol. 1997;48:218-24

32. Mussatto SI, Roberto IC. Xylitol production from high xylose concentration: evaluation of the fermentation in bioreactor under different stirring rates. J Appl Microbiol J. 2003;95:331-7.

33. Salvachúa D, Mohagheghi A, Smith H, Bradfield MFA, Nicol W, Black BA, et al Succinic acid production on xylose-enriched biorefinery streams by Actinobacillus succinogenes in batch fermentation. Biotechnol Biofuels. 2016;9:28

34. Bernal V, Castaño-Cerezo S, Cánovas M. Acetate metabolism regulation in Escherichia coli: carbon overflow, pathogenicity, and beyond. Appl Microbiol Biotechnol. 2016;100:8985-9001.

35. Lim HG, Lee JH, Noh MH, Jung GY. Rediscovering acetate metabolism: its potential sources and utilization for biobased transformation into valueadded chemicals. J Agric Food Chem. 2018;66:3998-4006.

36. Huang B, Yang H, Fang G, Zhang X, Wu H, Li Z, et al. Central pathway engineering for enhanced succinate biosynthesis from acetate in Escherichia coli. Biotechnol Bioeng. 2018;115:943-54.

37. Li Y, Huang B, Wu H, Li Z, Ye Q, Zhang YHP. Production of succinate from acetate by metabolically engineered Escherichia coli. ACS Synth Biol. 2016;5:1299-307.

38. Yuzbashev TV, Yuzbasheva EY, Sobolevskaya TI, Laptev IA, Vybornaya TV, Larina AS, et al. Production of succinic acid at low pH by a recombinant strain of the aerobic yeast Yarrowia lipolytica. Biotechnol Bioeng. 2010;107:673-82.

39. Celińska E, Ledesma-Amaro R, Larroude M, Rossignol T, Pauthenier C, Nicaud JM. Golden Gate Assembly system dedicated to complex pathway manipulation in Yarrowia lipolytica. Microb Biotechnol. 2017:10:450-5.

40. Larroude M, Park YK, Soudier P, Kubiak M, Nicaud JM, Rossignol T. A modular Golden Gate toolkit for Yarrowia lipolytica synthetic biology. Microb Biotechnol. 2019;12:1249-59.

41. Le Dall MT, Nicaud JM, Gaillardin C. Multiple-copy integration in the yeast Yarrowia lipolytica. Curr Genet. 1994;26:38-44.

42. Lõoke $M$, Kristjuhan $\mathrm{K}$, Kristjuhan A. Extraction of genomic DNA from yeasts for PCR-based applications. Biotechniques. 2011;50:325-8.

43. Bradford MM. A rapid and sensitive method for the quantitation of microgram quantities of protein utilizing the principle of protein-dye binding. Anal Biochem. 1976;72:248-54.

44. Yablochkova EN, Bolotnikova OI, Mikhailova NP, Nemova NN, Ginak Al. The activity of xylose reductase and xylitol dehydrogenase in yeasts. Microbiology. 2003;72:414-7. 
45. Pateraki C, Almqvist H, Ladakis D, Lidén G, Koutinas AA, Vlysidis A. Modelling succinic acid fermentation using a xylose based substrate. Biochem Eng J. 2016;114:26-41.

46. Borges ER, Pereira N. Succinic acid production from sugarcane bagasse hemicellulose hydrolysate by Actinobacillus succinogenes. J Ind Microbio Biotechnol. 2011;38:1001-11.

47. Wang H, Pan J, Wang J, Wang N, Zhang J, Li Q, et al. Succinic acid production from xylose mother liquor by recombinant Escherichia coli strain. Biotechnol Biotechnol Equip. 2014;28:1042-9.

48. Yu J, Li Z, Ye Q, Yang Y, Chen S. Development of succinic acid production from corncob hydrolysate by Actinobacillus succinogenes. J Ind Microbiol Biotechnol. 2010;37:1033-40.

49. Liu R, Liang L, Chen K, Ma J, Jiang M, Wei P, et al. Fermentation of xylose to succinate by enhancement of ATP supply in metabolically engineered Escherichia coli. Appl Microbiol Biotechnol. 2012;94:959-68.
50. Bao H, Liu R, Liang L, Jiang Y, Jiang M, Ma J, et al. Succinic acid production from hemicellulose hydrolysate by an Escherichia coli mutant obtained by atmospheric and room temperature plasma and adaptive evolution. Enzyme Microb Technol. 2014;66:10-5.

51. Scholten E, Dägele D. Succinic acid production by a newly isolated bacterium. Biotechnol Lett. 2008;30:2143-6.

\section{Publisher's Note}

Springer Nature remains neutral with regard to jurisdictional claims in published maps and institutional affiliations.
Ready to submit your research? Choose BMC and benefit from:

- fast, convenient online submission

- thorough peer review by experienced researchers in your field

- rapid publication on acceptance

- support for research data, including large and complex data types

- gold Open Access which fosters wider collaboration and increased citations

- maximum visibility for your research: over $100 \mathrm{M}$ website views per year

At BMC, research is always in progress.

Learn more biomedcentral.com/submissions 